Brown, RB, Saunders MNK, and Beresford, R (2006) You owe it to yourselves: the financially literate manager Accounting Forum, 30.2, 179-191

\title{
You Owe It To Yourself: The Financially Literate Manager
}

\section{Abstract}

There is an important benefit for businesspeople who are financially literate. Financial literacy helps them to function efficiently at work because they are able to evaluate the information needed to make decisions that have financial ramifications or consequences.

Research into the financially literate has tended to concentrate on personal finance issues involving the general public. The focus of this paper, however, is on entrepreneurs who, in their first year as owners or managers of small firms, are required to understand the financial position and activities of their organisations, and thus do not need to take the activities, statements and advice of their accountants and financial advisors on trust.

Using data collected from 147 small businesses over their first year of trading, the findings provide evidence of a degree of financial illiteracy which has implications for the success or failure of this section of the business community.

Keywords: financial literacy small firms owner-managers

\section{Introduction}

The term 'financial literacy' has, like its relatives - computer literacy, statistical literacy, visual literacy, electronic literacy, political literacy - become familiar and, like them, is a term that carries an unclear meaning. For many users of these terms, 'literacy' is a synonym for 'awareness' or 'ability' or 'mastery' or 'skill', and for others, 'literacy' means only the ability to read write, and they reject the use of the word as a metaphor for any other kind of ability. There is a subtext to these varied literacies, however, which has a moral dimension, and holds that people ought to be literate in these areas, and that they are inadequate if they are not. 
As a consequence, bodies and centres have been set up to correct this lapse from the right path. The UK has the Financial Literacy Centre based at the University of Warwick and the Money Management Council. In the USA, there are the National Endowment for Financial Education, and the Financial Literacy Center. There are also programmes such as the Right Start Coalition for Financial Literacy in Canada, and the Jump\$tart Coalition for Personal Financial Literacy in the USA.

The focus of these bodies and programmes tends to be individuals, and the major concern is to enable members of the general population to understand their own financial situation, so that, if and when, they make investments, they are clear about their decisions and choices.

The focus of this paper is the segment of the population who are concerned with small businesses, and who, as owners or managers of firms, need to understand the financial position and activities of their organisations, and thus do not need to take the statements and activities of their accountants and financial advisors on trust.

The order of the paper is as follows: the next section deals with the term 'literacy' and considers what financial literacy might actually be. The subsequent section covers the literature that exists concerning the term, and the following section describes the context of and rationale for the research which has been undertaken. Then the research process is provided. The findings precede the final section, which considers the implications of a lack of financial literacy in this section of the business community.

\section{Literacy and financial literacy}

While to be literate means that one can read and write, it also means that, as the Oxford English Dictionary defines, one is 'acquainted with letters or literature; educated, instructed, learned'. Literacy has been researched through the perspective of a number of disciplines - psychology, linguistics, social anthropology, pedagogy. The number of those in the UK who have been through compulsory schools and who are unable to read and write, or have an extremely limited ability to do so, is estimated at many thousands.

Literacy is important because people who are literate no longer have to be content with what other people choose to teach them, but can find out for themselves what they want to know. The added value of being literate is the creation of 
opportunities for the extending of knowledge, learning and understanding, the ability to make informed choices and to make sense of the world, and material benefits in terms of occupational status and wealth accumulation.

From this viewpoint, reading and writing are skills necessary for the attainment of literacy, but they do not constitute literacy itself. While not present in the bald dictionary definition, there is a third element to literacy. To be literate is not only to be able to read and write, but also to understand that which has been read or written. And it is this third element which is present in the concept of financial literacy which uses the word 'literacy' as a metaphor, is a figure of speech in which a name or descriptive term is transferred to some object different from, but analogous to, that to which it is properly applicable. Literacy as a metaphor involves the ability to read and comprehend financial information, whether presented as text or 'pictures', in other words, the ability to read and understand fundamental financial statements, including a company's balance sheet, income statement, and cash flow statement.. Thus, financial literacy will include numeracy, the 'ability with, or knowledge of, numbers', and is, according to Schagen and Lines (1996), the ability to make informed judgements and to take effective decisions regarding the use and management of money.

We now have a definition part literal and part metaphor for a concept that concerns reading, writing and understanding financial information. Something else needs to be added - that financial literacy has a purpose. People who are financially literate have become so because it will help them to evaluate the information they need to make decisions that have financial ramifications or consequences.

\section{The literature}

One of the difficulties of providing an overview of research undertaken into financial literacy is that other terms are used by those researchers, and it is uncertain whether these are intended as synonyms or as different concepts. There is research into financial awareness, for example, that of by Peel and Pendelbury (1998) and Peel et al (1991) into the financial awareness of employees who hold shares in their own companies through internal shareholding schemes, and that of Marriott and Mellett $(1991,1994)$. However, in their 1995 and 1996 publications, they are researching 'financial skills', though (1996, p. 72) they state 'the financial skill index used in the study is one proxy for financial awareness'. Marriott and Mellett's (1996, 
p. 64) definition of financial awareness as 'the manager's ability to understand and analyse financial information and act accordingly', is a variant of the Schagen and Lines (1996) definition given above.

Research into financial literacy has tended to concentrate on personal finance issues. The Financial Services Agency (1998) reported that the level of financial literacy in the population is generally low, that people tend to have low levels of understanding of what their financial needs are, what products are available to satisfy those needs, and are not aware of where and how to find out what they need to know.

One of the main reasons that companies are required to produce annual reports is to provide information to shareholders which they can then use to influence the companies' behaviour or to make investment decisions. Lee and Tweedie's research into private shareholders in two UK companies (1975a, 1975b, 1976, 1977) has found that shareholders paid little attention to the financial reports. When, twenty years later, Bartlett and Chandler (1997) replicated Lee and Tweedie's work in order to examine whether the changes in the financial reporting environment (such as introducing a cash flow statement and an operating and financial review) had made any difference, they found that the annual report is still not widely read and few shareholders read the new statements.

The problem is that however it is defined - as financial literacy, awareness or skills - what is being referred to is a process. There are always adjectives attached - low, inadequate, adequate, good, better, excellent - just as to the concept of literacy itself. From a state of illiteracy, one moves forward and progresses, reaches plateaux, improves again, reaches the highest/best state of literacy one is capable of.

\section{Aims of the research}

It seems logical to consider that financial awareness is a prerequisite to financial literacy, and that financial skills develop alongside both awareness and literacy. It is from this line of reasoning that the research problem evolved. The research aims were threefold:

- to elicit the perceived financial awareness, skills, and literacy of a sample of entrepreneurs over their first year of business 
- to establish the importance attributed to financial awareness, skills, and literacy by these entrepreneurs

- to consider the implications of these findings for entrepreneurs' abilities to 'read' and 'write', and understand financial information.

\section{The site and context of the research}

"Training in Business Basics" is a programme designed specifically for the owner-managers of new small business of less than ten employees. Its aim is to support them over the first three years of operating. The programme consists of modules which are delivered over a period of three years on a weekly basis via the internet, supported by email contact, an electronic library, including frequently asked questions and, for the duration of the first year, a small business mentor allocated to each of the small businesses. Each mentor meets with each of his/her small business owner-managers three times during this year, as well as offering email and telephone support.

\section{The programme members}

The programme began in January 2003 with 147 small businesses from the South East Enterprise and Development Agency (SEEDA) region. At the end of the first year of operation, 122 of these were still with the programme. Of these 122 owner-managers, $26 \%$ had not started trading at the start of the programme, $23 \%$ had been trading for less than 6 months, $21 \%$ for 6 to 12 months, whilst $30 \%$ had been trading for over one year. Of the remaining 25 small businesses in the initial 147, 8 businesses had ceased trading, 12 were 'on hold', and 5 had lost interest in, or resigned from, the programme. This represents a business survival rate of $86 \%$.

Within this paper, we are interested in the small business owner-managers' perceptions of their own financial literacy, and how these altered over time. Inevitably, our sample represents an extreme case, due to support given over the year through the programme.

\section{Data collection and analysis}

Data were collected by questionnaire from the owner-managers of these small business at the start of the programme, after six months (when they were expected 
to have completed their mid-year financial forecast), and at the end of the first year of the programme. Each questionnaire was designed to reflect the stage which the owner-managers' businesses had reached. Consequently, although a number of the questions remained core across all three periods, others were stage-specific. Each questionnaire consisted predominantly of closed questions, and covered issues relating to the owner-managers' financial perceptions and expectations, as well as a wide range of programme stage-related factors (Appendix 1).

Questionnaires were administered on-line via email to 147 owner managers and, although responses were not anonymous, assurances were given regarding confidentiality. Upon return, data from the questionnaires were collated and merged into one file covering all three stages. 95 owner-managers responded to the questionnaire at the start of the programme representing a $65 \%$ response rate. Of these, 77 also answered a subsequent questionnaire after six months (comprising a cohort survival rate of those responding at start of programme of $81 \%$ ), and 72 answered the questionnaire at the end of the first year (comprising a survival rate of $76 \%$ ). It should be noted that 64 owner-managers answered all three questionnaires. Subsequent analysis was undertaken using the SPSS package. Analysis of those responses relating to financial perceptions and expectations are detailed below.

\section{The findings}

\subsection{Information about the full sample}

$\left(^{* * * *}\right.$ Reva, I can't see how this can go in a table, despite what the referees say!***)

The 95 owner-managers participating in the research were composed of 31 from the leisure and tourism sector, 27 from bioscience, 25 from information technology, 6 from agriculture, 3 from electronics, 2 from automotive engineering, and 1 from aerospace.

Where business structure is concerned, 48 were limited companies, 26 were sole traders, 7 were in partnerships, 2 were in limited liability partnerships, 2 were university-based consultancies, 1 was a not-for-profit company, 1 was an emerging social firm, and 1 a possible spin-out.

The owner-managers divided into $66(70 \%)$ male and $28(30 \%)$ female. One was under 21 (1\%), 30 were between 22 and 34 (32\%), 32 were between 35 and 44 
(34\%), 23 were $45-54$ (25\%), 6 were between 55 and 64 (6\%), and 2 were 65 or older (2\%).

The owner-managers' qualifications ranged from the $17 \%$ who had the older qualifications of $O$ and A levels, GCSEs and CSEs, through the $5 \%$ who had NVQ levels $1-5$ or $\mathrm{HNC} / \mathrm{HND}$ qualifications, to $40 \%$ who had a first degree, and $37 \%$ who had a higher degree.

And, finally, $41 \%$ had run a business before, and $59 \%$ had not done so.

\subsection{Perceptions of financial awareness and literacy}

A wide number of business-related issues was covered in the three questionnaires issued at the start of the programme, after six months, and at the end of the first year. This paper highlights the various finance-related data, some of which is compared and contrasted with the other non-finance data that has been collected and analysed. The owner-managers were asked "To what extent do you believe you have invested financially in your business?". Table 1 provides responses over the 12-month period of the research.

Table 1: Extent of financial investment

\begin{tabular}{lccc}
\hline & Start \% & 6 months \% & 1 year \% \\
\hline not at all & 21 & 17 & 17 \\
little & 18 & 23 & 15 \\
moderate & 38 & 36 & 36 \\
heavy & 22 & 23 & 32 \\
Total (=100\%) & 95 & 77 & 72 \\
& & & \\
\hline
\end{tabular}

Responses did not differ significantly between those who had been running a business for over 6 months when they started the programme, and others (chi sq = $2.296, d f=3, p=0.513)$. They do, however, show an increase in the perceived extent of financial investment over the first year of the training programme.

At the start of the programme, owner-managers were asked to indicate about which of a list of 17 issues they had sought external advice in the previous six months. Table 2 provides their responses with finance/accounts, ranked at second, after the issue of 'funding' for the small business. 
Table 2: Issues about which owner-managers who had sought prior external advice

\begin{tabular}{l|c|c}
\hline \multicolumn{1}{c|}{ Issue } & $\begin{array}{c}\text { sought external } \\
\text { advice (no. = 73) }\end{array}$ & rank \\
\hline funding & $56 \%$ & \\
finance/accounts & $\mathbf{5 2 \%}$ & $\mathbf{2}$ \\
business planning & $48 \%$ & 3 \\
insurance & $42 \%$ & 4 \\
IT & $34 \%$ & 5 \\
business law & $33 \%$ & 6 \\
marketing/sales & $30 \%$ & 7 \\
pensions & $25 \%$ & 8 \\
health and safety & $22 \%$ & 9 \\
training & $22 \%$ & 10 \\
recruitment & $21 \%$ & 11 \\
property/relocation & $19 \%$ & 12 \\
distribution & $14 \%$ & 13 \\
exporting & $12 \%$ & 14 \\
manufacturing & $8 \%$ & 15 \\
quality management & $5 \%$ & 16 \\
other area(s) & $4 \%$ & 17 \\
& & \\
\hline
\end{tabular}

The owner-managers were also asked to indicate those areas of business knowledge in which they had undertaken training prior to starting the programme. Of those who responded, $11 \%$ had undertaken finance/accounts training, a relatively low proportion, given the use of external advice highlighted by Table 2. Thus, although they were seeking advice on finance and accounts issues, they were rarely undertaking training in this area.

Table 3: Participated in training before starting programme

\begin{tabular}{l|c}
\hline Area of business knowledge & $\%$ \\
\hline & $23 \%$ \\
IT & $20 \%$ \\
managerial training & $18 \%$ \\
marketing/sales & $12 \%$ \\
other area(s) & $\mathbf{1 1 \%}$ \\
finance/accounts & $6 \%$ \\
customer service & $2 \%$ \\
export training & $52 \%$ \\
overall participation in training & 75 \\
Total (=100\%) & \\
\end{tabular}


What is interesting is the change in their confidence in their own personal skills concerning financial matters and their accounts during the first year of the programme (See Table 4). Whilst there had been a diminution of those who were 'not confident at all' in their ability from nearly $10 \%$ down to $1.4 \%$, there was only a $1.5 \%$ growth in those who were 'very confident'. When the level of confidence in finance/accounts is compared with that in the other areas of business knowledge in Table 3, it was found that it was lower than for any of the other areas at each of the three time periods.

Table 4: Confidence in own personal skills with finance and accounts

\begin{tabular}{l|c|c}
\hline & Start & 1 year \\
\hline 1 (not confident at all) & $10 \%$ & $1 \%$ \\
2 & $33 \%$ & $25 \%$ \\
3 & $35 \%$ & $42 \%$ \\
4 & $17 \%$ & $25 \%$ \\
5 (very confident) & $5 \%$ & $7 \%$ \\
Total (=100\%) & 94 & 72 \\
& & \\
\hline
\end{tabular}

Responses did not differ significantly between those who had been running a business for over 6 months when they started the programme and others (chi sq = $2.538 \mathrm{df}=2,=0.281)$. When asked to rate their confidence in preparing a cash flow forecast, the same pattern emerges. Whilst the proportion who were "not confident at all' at the start (16\%) had fallen to $6 \%$ by the end of the first year of the programme, the proportion who were 'very confident' had only risen from $17 \%$ to $20 \%$. Again, responses did not differ significantly between those who had been running a business for over 6 months when they started the programme and others (chi $s q=3.66, d f=4, p=0.433$ ).

Within the year, mean confidence in preparing a cash flow forecast rose from 3.13 to 3.49. However, six months into the programme, just after participants were expected to have prepared their mid-year forecast and received relevant training, the proportion of respondents who felt very confident was higher $(31 \%)$ than at other times in the programme. A series of t-tests comparing confidence scores at different times in the programme reveals that confidence in preparing a cash flow statement increased significantly between the start of the programme and when they were expected to have prepared their mid year-forecast $(t=-2.803$, $d f=74, p=.006)$, but not subsequently. It should be noted, however, that respondents were still 
significantly more confident at the end of the year than at the start of the programme $(\mathrm{t}=-2.308, \mathrm{df}=67, \mathrm{p}=.020)$.

The extent of the importance accorded by responding businesspeople to financial literacy is revealed in responses to the question concerning the frequency of the use of cash flow forecasts six months after the start of the programme. $20 \%$ had not yet prepared a cash flow forecast, but did plan to do so, while $4 \%$ stated that they had no intention of doing so. To counter this, $42 \%$ responded that they had used their cash flow forecast at least once a month (Table 5).

Table 5: $\quad$ Frequency of use of cash flow forecasts six months into the programme

\begin{tabular}{l|c}
\hline frequency of use & $\%$ \\
\hline & \\
at least once a week & $9 \%$ \\
at least once a month & $33 \%$ \\
at least once a quarter & $10 \%$ \\
at least once a year & $1 \%$ \\
less than once a year & $1 \%$ \\
in the process of preparing one & $10 \%$ \\
not looked at it since it was prepared & $12 \% \wedge$ \\
not yet prepared one but plan to & $20 \%$ \\
not yet prepared one and don't plan to & $4 \%$ \\
Total (=100\%) & 77 \\
\end{tabular}

In summary, these small owner-managers perceived their own financial business knowledge to be lower than for other areas of business knowledge used in running a business. Although this had increased significantly over the year, the knowledge still had a low rank. Whilst this lack of skills appeared to be recognised by their seeking external advice in finance/accounts, they had rarely undertaken training prior to the start of the programme.

\subsection{Perceived importance of financial awareness, skills and literacy}

The owner-managers were asked to rank the importance to them of seven areas of business knowledge highlighted in Table 3 at the start of the programme, after 6 months and after a year. At each stage finance/accounts was ranked within the bottom three, being less important than marketing/selling, technical (job-related) skills, interpersonal skills and business planning. The owner-managers were also asked to estimate how well they though they were doing in each of these areas after 
six months of operation and then after one year. This information is provided in Table 6. Finance was ranked last both times, and links with the earlier information on their confidence at the start of the programme (see Table 4). It was a highly ranked area for seeking advice prior to starting the programme, yet was ranked low in terms of formal training! This appeared to be because, relative to other areas, finance was seen as relatively unimportant in the day-to-day running the business throughout the programme.

Table 6: Relative mean score of perception of doing well in areas of business knowledge

\begin{tabular}{l|c|c|c|c}
\hline Area of business knowledge & $\mathbf{6}$ months & rank & $\mathbf{1}$ year & rank \\
\hline the business as a whole & 3.33 & & & \\
technical (job related) skills & 4.13 & 1 & 3.68 & \\
interpersonal skills & 3.82 & 2 & 2.94 & 2 \\
IT & 3.61 & 3 & 2.74 & 5 \\
managerial skills & 3.52 & 4 & 2.75 & 4 \\
business planning & 2.91 & 5 & 2.53 & 6 \\
marketing/sales & 3.26 & 6 & 3.32 & 1 \\
finance/accounts & $\mathbf{3 . 2 5}$ & $\mathbf{7}$ & $\mathbf{2 . 4 7}$ & $\mathbf{7}$ \\
& & & & \\
\hline
\end{tabular}

Six months into the programme, the owner-managers were asked about the most basic aspect of financial literacy - 'Who does the book-keeping?' Despite their low perceptions of their own financial awareness and literacy, $55 \%$ of the ownermanagers stated that they did their own books, whilst only $17 \%$ employed an accountant (Table 7).

Table 7: Who does the book-keeping?

\begin{tabular}{l|c}
\hline book keeper & percentage \\
\hline self & $55 \%$ \\
staff member doing it as part of his/her job & $17 \%$ \\
external book keeper & $8 \%$ \\
accountant & $15 \%$ \\
self and accountant & $2 \%$ \\
Other & $3 \%$ \\
Total (=100\%) & 60 \\
\end{tabular}

Most of the time spent on business activities during the week was spent on sales, double the amount spent on areas such as marketing and IT. Time spent on 
book-keeping, i.e. the financial side of the business ranked last, with 2 hours a week devoted to this aspect of running the firm. (See Table 8)

Table 8: Hours spent on business activities

\begin{tabular}{l|c|c}
\hline & hours & rank \\
\hline sales & 12.6 & 1 \\
\hline marketing & 5.7 & 2 \\
\hline IT & 4.5 & 3 \\
\hline business planning & 3.4 & 4 \\
\hline administration & 4.1 & 5 \\
\hline managing staff & 3.3 & 6 \\
\hline bookkeeping & $\mathbf{2 . 0}$ & $\mathbf{7}$ \\
\hline
\end{tabular}

One year into the programme, the owner-managers were asked to rank nine areas in terms of where they felt that they needed help (Table 9). They ranked marketing as $1^{\text {st }}$, managing staff as $9^{\text {th }}$, and book-keeping ranked $5^{\text {th }}$, together with work/life balance. Again, despite having admitted to having low confidence in financial areas (Table 3), these appeared under midway in the ranking, supporting the finding that financial literacy was not perceived as important as other areas of business knowledge.

Table 9: $\quad$ Areas where help required 1 year into programme

\begin{tabular}{l|c|c}
\hline Area & need most help \% & rank \\
\hline & & \\
marketing & $51 \%$ & 1 \\
business planning & $49 \%$ & 2 \\
sales & $44 \%$ & $3=$ \\
time management & $44 \%$ & $3=$ \\
finance/accounts & $35 \%$ & $\mathbf{5 =}$ \\
work/life balance & $35 \%$ & $5=$ \\
IT & $32 \%$ & 7 \\
administration & $30 \%$ & 8 \\
managing staff & $23 \%$ & 9 \\
& & \\
\hline
\end{tabular}

\section{Discussion: implications for business people's financial literacy}

The small businesspeople involved in the programme have produced a contradictory picture of the degree of their financial awareness, skills, and literacy. Although these people appeared to be aware of their own lack of financial literacy, they did not perceive this to be important relative to other aspects of running a small business. 
Although they recognised their own limitations, the majority still undertook their bookkeeping themselves, very few using the services of an accountant.

It would seem that these owner-managers, while they might have the ability to read and understand fundamental financial statements, do not have the ability to make informed judgements and to take effective decisions regarding the use and management of money (Schagen and Lines, 1996). Despite their special need for financial literacy, the owner-managers in this study, like the general population (The Financial Services Agency, 1998) have low levels of understanding of what their financial needs are, what products, services and techniques are available to satisfy those needs, and are not aware of where and how to find out what they need to know.

There was evidence of a degree of financial awareness, and financial skills, but perhaps not to the degree where the owner-managers could, with confidence, understand and analyse the financial information required, and then act accordingly.

This is not conducive to the creation of a small firm which flourishes, expands and is efficiently run. It would seem that the owner-managers on the programme are more concerned with selling their product or service than with the problem of getting the 'finance' right. 


\section{REFERENCES}

Bartlett, S.A. \& Chandler, R.A. (1997) The corporate report and the private shareholder: Lee and Tweedie twenty years on, British Accounting Review, 29, 245-261.

Financial Services Authority. (1998) Promoting public understanding of financial services: A strategy for consumer education. November, Consultation Paper 15, London: Financial Services Authority.

Financial Services Authority. (1988) Consumer education: A strategy for promoting public understanding of the financial system. London : Financial Services Authority.

Jennings, M., Nelson, A. \& Boucher, A. (1997) Financial literacy: the cost of ignorance, RSA Journal, March, 31-35.

Lee, T. A. and Tweedie, D. P. (1975a) Accounting information: an investigation of private shareholder usage, Accounting and Business Research, Autumn, 6, 4, 280-291.

Lee, T.A. and Tweedie, D.P. (1975b) Accounting information: an investigation of private shareholder understanding, Accounting and Business Research, Winter, 6, 4, 3-17.

Lee, T.A. and Tweedie, D.P. (1973) The private shareholder: his sources of financial information and his understanding of reporting practices, Accounting and Business Research, Autumn, 304-313.

Lee, T.A. \& Tweedie, D.P. (1977) The private shareholder and the corporate report. London: Institute of Chartered Accountants in England and Wales.

Marriott, D.N. \& Mellett, H.J. (1991) The financial awareness of managers in the reformed NHS. Occasional Research Paper No. 10, London: Association of Chartered Certified Accountants,.

Marriott, D. N. \& Mellett, H. J. (1994) Resources, Responsibility and Understanding in the NHS. Research Report No. 37, London: Association of Chartered Certified Accountants.

Marriott, D. N. \& Mellett, H. J. (1995) The level of financial skills of National Health Service Managers, Financial Accountability and Management, 11, 3, 271-282.

Marriott, D.N. \& Mellett, H.J. (1996) Health care managers' financial skills: measurement, analysis and implications, Accounting Education, 1996, 5(1): 61-64.

Peel, M. J. \& Pendlebury, M. (1998) Employee share ownership and financial awareness: Some further evidence, ACCA Research Report No. 24, London: Association of Chartered Certified Accountants.

Peel, M. J., Pendlebury, M. \& Groves, R. E. V. (1991) Employee share ownership, 'financial awareness' and the reporting of financial information to employees, Research Report No. 22, London: Association of Chartered Certified Accountants.

Schagen, S. \& Lines, A. (1996) Financial Literacy in Adult Life: A Report to the NatWest Group Charitable Trust. Slough: National Foundation for Educational Research. 


\section{Research Centre \\ Wheatley \\ Oxford 33 1HX}

Tel: 01865485638

Fax: 01865485871

Email: revabrown@brookes.ac.uk

3 June 2005

Prof. Glen Lehman

Accounting Forum

School of Accounting and Information Systems

Universitiy of South Australia

Adelaide, SA, 5001

Australia

Dear Glen,

Re: You Owe It To Yourself: The Financially Literate Manager

Thank you for your email of 1 June, explaining that you never received the copy of the paper I emailed to you in March.

Here are four hard copies, and I appreciate your offer to expedite the process.

I look forward to hearing from you in due course.

Best wishes,

Reva Brown

Prof. of Management Research 
Appendix 1: Questions asked in the questionnaire at each stage of the research

\begin{tabular}{|c|c|c|c|}
\hline \multirow[t]{2}{*}{ Question } & \multicolumn{3}{|c|}{ stage } \\
\hline & 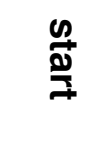 & 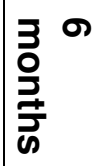 & $\underset{\$}{\stackrel{\$}{ٍ}}$ \\
\hline $\begin{array}{l}\text { Core demographic data: Respondent's name, Business name } \\
\text { Other demographic data: Respondent's gender, age, educational level, } \\
\text { technical experience in business area, experience of running a business, number } \\
\text { of full time and part time employees } \\
\text { What is your business structure (Sole trader, Partnership, Limited Company, } \\
\text { Limited liability partnership, Other (please describe) }\end{array}$ & $\begin{array}{l}\checkmark \\
\checkmark\end{array}$ & $\checkmark$ & $\checkmark$ \\
\hline $\begin{array}{l}\text { When did your business start trading (not started, up to } 3 \text { months, }>3-6 \\
\text { months, }>6-12 \text { months, over } 1 \text { year }\end{array}$ & $\checkmark$ & $\checkmark$ & $\checkmark$ \\
\hline $\begin{array}{l}\text { How motivated do you feel about running your business? ( } 5 \text { point scale } \\
1=\text { feeling discouraged, } 5=\text { raring to go) }\end{array}$ & $\checkmark$ & $\checkmark$ & $\checkmark$ \\
\hline $\begin{array}{l}\text { To what extent do you believe you have invested financially in your } \\
\text { business? (Heavily, moderately, little, not at all) }\end{array}$ & $\checkmark$ & $\checkmark$ & $\checkmark$ \\
\hline $\begin{array}{l}\text { How confident are you in your skills in the following areas? ( } 5 \text { point scale: } \\
\text { not at all confident, } 5=\text { very confident) }\end{array}$ & $\checkmark$ & & $\checkmark$ \\
\hline a) Marketing/sales & $\checkmark$ & & $\checkmark$ \\
\hline b) Interpersonal & $\checkmark$ & & $\checkmark$ \\
\hline c) Finance/accounts & $\checkmark$ & & $\checkmark$ \\
\hline d) Managerial & $\checkmark$ & & $\checkmark$ \\
\hline e) Business planning & $\checkmark$ & & $\checkmark$ \\
\hline f) IT & $\checkmark$ & & $\checkmark$ \\
\hline g) Technical (e.g. plumbing skills for plumber) & $\checkmark$ & & $\checkmark$ \\
\hline $\begin{array}{l}\text { How important do you think each of the following skills is in running your } \\
\text { business at the moment? ( } 5 \text { point scale: } 1=\text { not at all important, } 5=\text { very } \\
\text { important) }\end{array}$ & $\checkmark$ & & $\checkmark$ \\
\hline a) Marketing/sales & $\checkmark$ & & $\checkmark$ \\
\hline b) Interpersonal & $\checkmark$ & & $\checkmark$ \\
\hline c) Finance/accounts & $\checkmark$ & & $\checkmark$ \\
\hline d) Managerial & $\checkmark$ & & $\checkmark$ \\
\hline e) Business planning & $\checkmark$ & & $\checkmark$ \\
\hline f) IT & $\checkmark$ & & $\checkmark$ \\
\hline g) Technical (e.g. plumbing skills for plumber) & $\checkmark$ & & $\checkmark$ \\
\hline $\begin{array}{l}\text { How confident are you to prepare a business plan? ( } 5 \text { point scale: } 1=\text { not at } \\
\text { all confident, } 5=\text { very important) }\end{array}$ & & $\checkmark$ & $\checkmark$ \\
\hline $\begin{array}{l}\text { How confident are you to prepare a cash flow forecast? ( } 5 \text { point scale: not at } \\
\text { all confident, } 5=\text { very important) }\end{array}$ & $\checkmark$ & $\checkmark$ & $\checkmark$ \\
\hline $\begin{array}{l}\text { Have you written a business plan? (Yes -it has been useful, Yes-it has not } \\
\text { been useful, No, in process of writing one) }\end{array}$ & $\checkmark$ & $\checkmark$ & $\checkmark$ \\
\hline $\begin{array}{l}\text { Have you prepared a cash flow forecast? (Yes -it has been useful, Yes-it has } \\
\text { not been useful, No, in process of writing one) }\end{array}$ & $\checkmark$ & $\checkmark$ & $\checkmark$ \\
\hline $\begin{array}{l}\text { How often do you use your cash flow forecast? (at least once a week, at } \\
\text { least once a month, at least once a quarter, at least once a year, <once a year, } \\
\text { in process of preparing one, haven't looked at it since I prepared it, haven't yet } \\
\text { prepared one but plan to, haven't yet prepared one and don't plan to) }\end{array}$ & & $\checkmark$ & \\
\hline $\begin{array}{l}\text { Who does your book-keeping? (me, family member as a favour, staff member } \\
\text { as part of their job, external book leeper, accountant, not applicable-not yet } \\
\text { trading) }\end{array}$ & & $\checkmark$ & \\
\hline $\begin{array}{l}\text { On average, how many hours do you spend on these activities per week? } \\
\text { a) Marketing }\end{array}$ & & $\mid \begin{array}{l}\checkmark \\
\checkmark\end{array}$ & \\
\hline
\end{tabular}


b) Sales

c) Book-keeping

d) Managing staff

e) Business planning

f) IT

g) Adminisitration

h) Not applicable (not yet trading)

How well do you think you are doing in each of the following areas? (5 point scale: $1=$ not very well, $5=$ very well)

a) Marketing/sales

b) Interpersonal

c) Finance/accounts

d) Business planning

e) Managerial

f) IT

g) Technical (e.g. plumbing skills for plumber)

h) Running the business as a whole

What area/skill do you think you need most help in? (Tick all that apply)

a) Marketing

b) Sales

c) Administration

d) Finance/accounts

e) Managerial

f) Business planning

g) IT

h) Time management

i) Work-life balance

Have you sought external advice in any of the following areas in the past 6 months (tick all that apply)
a) Business Planning
b) Business Law
c) Funding
d) Insurance
e) Pensions
f) Finance/accounts
g) Quality management
h) Health and Safety
i) Recruitment
j) Training
k) Marketing/selling
l) IT
m) Manufacturing
n) Distribution
o) Property/relocation
p) Exporting
q) Other (please describe)

Have you or any of your staff participated in training in any of the following areas within the last 12 months? (tick all that apply)
a) Marketing/sales
b) Customer service
c) Finance/accounts
d) Managerial
e) IT
f) Export training
g) Other (please describe)
h) None 
